\title{
A NATURAL ANTISEPTIC ALTERNATIVE IN HAND SANITIZER GEL : A COMBINATION OF MIANA AND KEMUNING LEAVES EXTRACT
}

\author{
Afidatul Muadifah ${ }^{* 1}$, Dara Pranidya Tilarso ${ }^{2)}$, Ary Kristijono ${ }^{3)}$, Khoirul Ngibad ${ }^{4)}$, Nabila Putri \\ Salsabila ${ }^{5}$ \\ 1,2,3,5 Departement of Pharmacy, STIKES Karya Putra Bangsa, Tulungagung, Indonesia \\ ${ }^{4}$ Department of D-3 TLM, Maarif Hasyim Latif University, Sidoarjo, Indonesia \\ email: afidatul.muadifah@stikes-kartrasa.ac.id
}

\begin{abstract}
Abstrak
Penggunaan gel hand sanitizer saat ini menjadi jalan keluar untuk menjaga kesehatan dan kebersihan tangan agar lebih praktis dan mudah dibawa. Penelitian ini bertujuan untuk menghasilkan antiseptik alami dari kombinasi ekstrak daun Miana dan Kemuning terhadap Staphylococcus aureus dan Escherichia coli dalam bentuk gel. Gel hand sanitizer dibuat dari kombinasi ekstrak daun miana dan kemuning yang menunjukkan daya hambat optimum terhadap bakteri Staphylococcus aureus dan Escherichia coli. Kombinasi ekstrak daun Miana dan Kemuning dibuat dalam 3 variasi konsentrasi $(K 1=5 \%: 15 \%),(K 2=10 \%: 10 \%)$, dan $(K 3$ $=15 \%: 5 \%$ ). Formulasi gel hand sanitizer diuji kemampuannya sebagai antiseptik dan uji stabilitas fisik pada hari ke 0, hari ke 7, hari ke 14, hari ke 21, dan hari ke 28. Konsentrasi optimum dari kombinasi ekstrak daun miana dan kemuning sebagai antiseptik adalah pada kombinasi K3 = 15\%: 5\%. Kombinasi antiseptik alami K3 (NAK3) menunjukkan daya hambat sebesar 7,33 mm (terhadap Staphylococcus aureus) dan 09,00 mm (terhadap Escherichia coli) yang termasuk dalam kategori sedang. NAK3 memenuhi persyaratan untuk uji organoleptik, homogenitas, $\mathrm{pH}$, kemampuan menyebar, dan adhesi, serta stabil selama penyimpanan.
\end{abstract}

Kata kunci: antiseptik, miana, kemuning, gel, hand sanitizer

\begin{abstract}
The use of hand sanitizer gel is currently a more practical and portable way to maintain health and hand hygiene. This study aims to generate a natural antiseptic from a combination of Miana and Kemuning leaves extract toward Staphylococcus aureus and Escherichia coli in gel formulation. The hand sanitizer gel is made from a combination of Miana and Kemuning leaves extract which shows optimum inhibition against Staphylococcus aureus and Escherichia coli bacteria. The combination of Miana and Kemuning leaves extracts was made in 3 variations of concentration $(K 1=5 \%: 15 \%),(K 2=10 \%: 10 \%)$, and $(K 3=15 \%: 5 \%)$. The hand sanitizer gel formulation tested its ability as an antiseptic and on physical stability test on day 0 , day 7 , day 14, day 21, and day 28. The optimum concentration of the combination of Miana and Kemuning leaves extracts as an antiseptic is at a combination of $K 3=15 \%$ : $5 \%$. The combination K3 Natural Antiseptic (NAK3) showed an inhibitory power of $7.33 \mathrm{~mm}$ (against Staphylococcus aureus) and $09.00 \mathrm{~mm}$ (against Escherichia coli) which was included in the moderate category. The NAK3 meets the requirements for organoleptic tests, homogeneity, $\mathrm{pH}$, spreadability, and adhesion, and is stable during storage.
\end{abstract}

Keywords: antiseptic, miana, kemuning, gel, hand sanitizer

\section{INTRODUCTION}

During the Covid-19 Pandemic, there was a public health emergency. Therefore, prevention efforts must be carried out as soon as possible. The spokesperson for the COVID19 handling task force, Reisa Broto Asmoro, urged the public to implement 3M (Washing hands, keeping distance and moving away from crowds). Based on research, is washing hands can decrease the risk of suffering from diseases, it is not only Covid-19 but also other diseases caused by bacteria, which is $95 \%$ (Sinaga et al., 2020). Some of the bacteria found in human hands are Staphylococcus aureus (29\%), Escherichia coli (7.69\%), Bacillus sp (3.84\%), Enterobacter aeruginosa 
(5\%), and Staphylococcus epidermidis (2\%). Among these microorganisms, the bacteria Staphylococcus aureus and Escherichia coli are bacteria that are often found on the skin (L. Angga et al., 2015). Efforts to wash/clean hands can be done using hand sanitizer (in a gel formulation), which is more effective than washing hands with running water (Shu, 2013). The gel formulation has several advantages, namely, it has good spreadability, does not clog the skin pores, creates a cold effect due to the slow evaporation of water on the skin, and good drug release (Asngad et al., 2018). Hand sanitizer gel containing alcohol has better effectiveness in inhibiting microbes and requires a short time, but makes the skin dry, irritating (Widyawati et al., 2017).

Hand sanitizer gel made from natural ingredients is thought to be safer and does not cause skin irritation. Miana and Kemuning leaves are two plants in Indonesia that can be used as an alternative to natural antiseptics. The results of phytochemical screening of Miana leaves extract showed the content of alkaloids, flavonoids, saponins, and tannins (Tarigan et al., 2020). The ethanol extract of the leaves of Miana has antibacterial activity against S.aureus, $E$. coli, and $P$. Aeruginosa(Mpila et al., 2012). Another study states that Kemuning leaves contain chemical compounds which are secondary metabolites such as alkaloids, flavonoids, saponins, and tannins (Windono, 2002). The results of the research on the combination of Miana and Kemuning leaves extract has never been carried out so that an antibacterial activity test is needed.

Based on this description, a hand sanitizer gel formulation will be carried out from a combination of ethanol extracts from Miana and Kemuning leaves with compounds that have the potential to inhibit the growth of Staphylococcus aureus and Escherichia coli bacteria. The results of this study are expected to provide a scientific basis in the development process of Miana and Kemuning leaves extract and becomes a reference in making modern formulations.

This study aims to generate a natural antiseptic from a combination of Miana and Kemuning leaves extract toward Staphylococcus aureus and Escherichia coli in gel formulation.

\section{METHODS}

This research is experimental. This study used Miana leaves (Blitar, East Java) and Kemuning leaves (Tulungagung, East Java) from all branches, which has been identified and validated in MateriaMedicaBatu, Malang. The combination of Miana and Kemuning leaves extract was made in 3 variations of concentration, namely $(5 \%: 15 \%),(10 \%: 10 \%)$, and (15\%:5\%). The natural antiseptic is made from a combination of Miana and Kemuning leaves extract which shows optimum inhibition against Staphylococcus aureus and Escherichia Coli bacteria. Optimization of the gel-based hand sanitizer formulation using a variation of Carbomer 940 with a concentration of $0.5 \% ; 0.75 \%$; and $1 \%$. The optimum hand sanitizer gel was tested for its ability as an antiseptic and tested for physical stability on day 0 , day 7 , day 14 , day 21 , and day 28.

Materials: ethanol pro analytic (Merck); NA (KGaA), NB (KGaA), DMSO (panadialabora), 96\% alcohol (panadialabora), aqua dest (panadialabora), carbomer 940 (panadialabora), TEA (panadialabora), glycerin (panadialabora), methylparaben (panadialabora), propylparaben (panadialabora), green tea, HPMC, Na-CMC, Staphylococcus aureus, and Escherichia coli bacteria. The tools are incubator (Memmert), Autoclave (DaihanLabtech), Laminar Air Flow (LAF) (Heal Force AlphaClean 1300), and glassware (pyrex). This research conducted in February April 2021 in STIKES Karya Putra Bangsa Laboratory, Tulungagung Indonesia.

\section{Preparation of ethanol extract of Miana and Kemuning leaves}

The maceration extraction method was used in this study. The maceration method used 2,5 liter of $96 \%$ ethanol solvent at room temperature to wet every 1 kilogram of Miana and Kemuning leaves powder. This process takes 24 hours with stirring every 6 hours. The mixture of simplicity and ethanol is filtered to obtain macerate. This step is repeated twice (Rizal et al., 2016). The macerate was concentrated using the water bath method at a temperature of $40-50^{\circ} \mathrm{C}$ until a thick extract was formed. 
Antibacterial activity test of a combination of Miana and Kemuning leaves extract

Antibacterial activity test of the combination (K) of Miana and Kemuning leaves extracts $(\mathrm{K} 1=5 \%$ : 15\%); $(\mathrm{K} 2=10 \%$ : $10 \%)$; $(\mathrm{K} 3=15 \%$ : $5 \%)$ was performed using the disc diffusion method. The treatment medium was incubated at $37^{\circ} \mathrm{C}$ for $1 \times 24$ hours. In the clear zone formed around the disc, the inhibition zone diameter is measured using a caliper to determine its optimum inhibitory power. The combination with optimum inhibition is used as a natural antiseptic agent in hand sanitizer gel formulations.

\section{Gel Formulation}

\section{Standard formulation and natural antiseptic design}

The standard formulation of this study refers to the research formulation (Ati, 2019). Natural antiseptic were made by adding a combination of Miana and Kemuning leaves extract with a ratio of $15 \%$ : $5 \%$ as a natural antiseptic agent into the standard formulation which can be seen in Table 1 .

Table 1. Standard formulation and Natural Antiseptic Design (Ati, 2019)

\begin{tabular}{|c|c|c|}
\hline \multirow[b]{2}{*}{ Materials } & \multicolumn{2}{|c|}{ Concentration $(\% \mathrm{~b} / \mathrm{v})$} \\
\hline & $\begin{array}{l}\text { Standard } \\
\text { formulation }\end{array}$ & $\begin{array}{c}\text { Natural } \\
\text { antiseptic } \\
\text { design } \\
\text { (NAK3) }\end{array}$ \\
\hline Miana extract & - & 15 \\
\hline Kemuning extract & - & 5 \\
\hline Carbomer 940 & 0,5 & 0,5 \\
\hline Triethanolamine & 0,33 & 0,33 \\
\hline Glycerin & 10 & 10 \\
\hline Methyl paraben & 0,3 & 0,3 \\
\hline Prophylparaben & 0,03 & 0,03 \\
\hline Menthol & 0,08 & 0,08 \\
\hline Aquadestilata ad & 60 & 60 \\
\hline
\end{tabular}

According to Table 1, the gelling agent used is Carbomer 940. Carbomer 940 is easily dispersed in water because it belongs to the carbomerhydrophilic group and in a small concentration of $0.02-2 \%$ can be used as a gel base with sufficient consistency and is easy to wash with water. The use of Carbomer 940 base gives a fairly good appearance in each of the dosage formulas (Hidayati et.al., 2021).

\section{NAK3 Preparations}

NAK3 preparations are made by sprinkling carbomer 940 overheated aquadestilata. Carbomer 940 that has been sprinkled is stirred quickly in a mortar to avoid agglomerates until a gel mass forms, then neutralized by adding TEA as a base. Methylparaben was dissolved in aquadestilata, put in a mortar, and stirred until homogeneous. Methylparaben is used as a preservative intended to prevent the growth of microorganisms on the preparation. The propylparaben is added to the mortar, stirring until it is homogeneous. Furthermore, the combination of $\mathrm{K} 3$ was dissolved into aquadestilata and stirred until dissolved. Adding the remaining aquadestilata, then mixed until homogeneous and crushed to form a gel (Shu, 2013).

\section{Antibacterial activity test of NAK3}

The antibacterial activity test was carried out utilizing the disc diffusion method (paper disc), namely pure cultures of bacteria (Staphylococcus aureus and Escherichia coli) were evenly inoculated by dipping the tip of a sterile cotton bud in a liquid nutrient medium and scratching it on the surface of the NA plate medium until smooth. aseptically. Then dipped sterile paper discs or immersed in a gel formulation for 15 minutes. Disc paper containing the test sample is placed on the surface of the medium that has been inoculated with bacteria aseptically using sterile tweezers. The treatment medium was incubated at $37{ }^{\circ} \mathrm{C}$ for $1 \times 24$ hours. After 24 hours, a clear zone will form around the disc which shows the ability of the test compound to inhibit bacterial growth. After that, the diameter of the inhibition zone was measured using a caliper (Mawan et al., 2017). Measurement of zone inhibition was carried out $3 x$ replications (Yusriana et al., 2014).

\section{NAK3 Properties Test Organoleptic test}

Observations included color, smell, texture, and non-sticky impression of the gel. In general, a clear gel with a semi-solid concentration. The expected results of the organoleptic test were that there was no 
change in shape, color, and odor of the preparation during the stability test the preparation (Wasiaturrahmah, 2018).

\section{Homogeinity test}

The homogeneity test is carried out by applying 1 gram of gel sample to a suitable slide, then fixing it with a slide or other transparent material, and seeing whether the base preparation is smooth and the surface is even. The formulation must show a homogeneous arrangement and do not show any coarse grains (Wasiaturrahmah, 2018).

pH test

The $\mathrm{pH}$ test is a test carried out to determine the $\mathrm{pH}$ of the formulation. The $\mathrm{pH}$ requirement for topical formulations is between 4.5-6.5 (Naibaho et al., 2013). The suitability of skin $\mathrm{pH}$ with the $\mathrm{pH}$ of topical preparations affects the skin's acceptance of the formulation. The 10-gram formulation was dissolved in 100 $\mathrm{mL}$ aquadestilata and measured with a $\mathrm{pH}$ meter.

\section{Spreadability test}

The spreadability test was carried out by measuring the spread diameter of the formulation which was placed on a glass plate which was given a load of 50 grams per minute up to 150 grams. The formulation of a gel hand sanitizer is good and has a dispersion value ranging from 5-7 cm (Wasiaturrahmah, 2018).

\section{Adhesion test}

This test is carried out by placing $0.25 \mathrm{~g}$ of the gel sample between two object-glass on the tool and placing a load of $1 \mathrm{~kg}$ for 5 minutes, then the load is lifted and the tool is released at a load of 80 grams and the time obtained is recorded (Naibaho et al., 2013). Good adhesion of formulations is not less than 4 seconds (Yati et al., 2018).

\section{Drying time test}

The drying speed test shows the time it takes for each gel formula to dry on the skin of the palms (front and back of the skin of the palms with an area of $40-50 \mathrm{~cm}^{2}$ ) (Ningsih et al., 2016).

\section{RESULT AND DISCUSSION}

The purpose of making the extract is to obtain Miana and Kemuning leaves extract which is used as active compounds in making hand sanitizer gels. The initial stage was taking samples of Miana leaves in Srengat, Blitar and Kemuning leaves samples in Kedungwaru, Tulungagung. The next step is making a powder, then maceration is carried out with ethanol as a solvent. The result obtained is a thick extract yield of $7,86 \%$ (Miana) and 8,33\% (Kemuning). The water content of the Ethanol extract of Miana leaves is $8,7 \%$ and Kemuning leaves $9,02 \%$.

Table 2. Diameter of the zone of inhibition against Staphylococcus aureus andEscherichia coli

\begin{tabular}{llllllllll}
\hline \multirow{2}{*}{ No. } & Treatment & \multicolumn{6}{c}{ Inhibition Zone Diameter (mm) } \\
\cline { 3 - 9 } & & Staphylococcus aureus & \multicolumn{5}{c}{ Escherichia coli } \\
\hline & & R1 & R2 & R3 & Average & R1 & R2 & R3 & Average \\
\hline 1 & K1 (5\%:15\%) & 10,00 & 10,00 & 11,00 & 10,30 & 14,50 & 14,50 & 14,00 & 14,30 \\
2 & K2 (10\%: $10 \%)$ & 12,50 & 12,00 & 11,50 & 12,00 & 12,00 & 12,00 & 13,00 & 12,30 \\
3 & K3 (15\% : 5\%) & 13,00 & 12,50 & 12,00 & $\mathbf{1 2 , 5 0}$ & 13,00 & 12,00 & 13,00 & $\mathbf{1 2 , 6 6}$ \\
4 & Control(+) & 18,00 & 16,50 & 18,50 & 17,67 & 20,00 & 19,50 & 18,00 & 19,17 \\
5 & Control (-) & 00,00 & 00,00 & 00,00 & 00,00 & 00,00 & 00,00 & 00,00 & 00,00 \\
\hline
\end{tabular}

$\mathrm{R}=$ Replication; $\mathrm{K}=$ combination

The results of the antibacterial activity of the combination extract gave the optimum antibacterial activity to a concentration of K3 (10\%:5\%) with a diameter of 12,5 mm (against Staphylococcus aureus) and 12,66 mm (against Escherichia coli) (Table 2). The diameter response of the affected zone constitutes a strong bacterial growth response. 
Antibacterial Test Combination of Miana and Kemuning Leaves Extract

Antibacterial activity test of combination of Miana and Kemuning leaves extract ((5\%: $15 \%) ;(10 \%: 10 \%) ;(15 \%: 5 \%))$ or comparison ((1: 3); (1: 1); (3:1)) performed by the disc diffusion method. The treatment medium was incubated at $37^{\circ} \mathrm{C}$ for $1 \times 24$ hours (Darsana et al., 2012). In the clear zone formed around the disc, the inhibition zone diameter is measured using a caliper to determine its optimum inhibitory power. The results of observations and measurements of the diameter of the clear inhibition zone formed around the disc paper show that the inhibition of the combination of ethanol extract of Miana leaves and Kemuning leaves against Staphylococcus aureus and Escherichia coli can be seen in Figure 1.
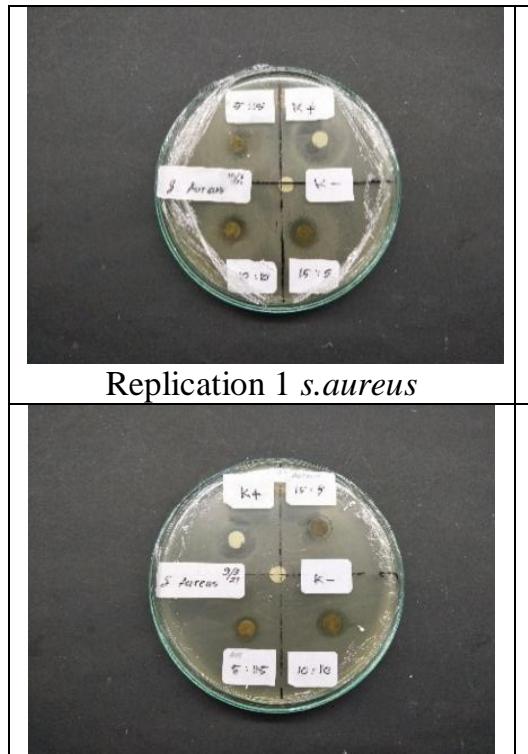

Replication 2 s.aureus

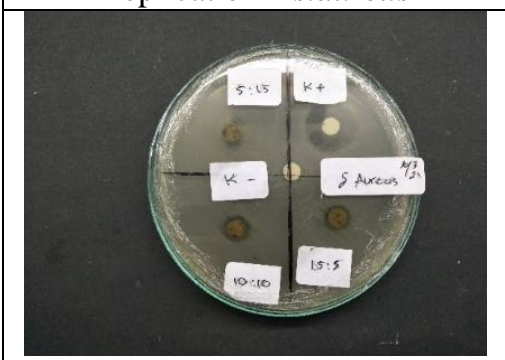

Replication 3 s.aureus

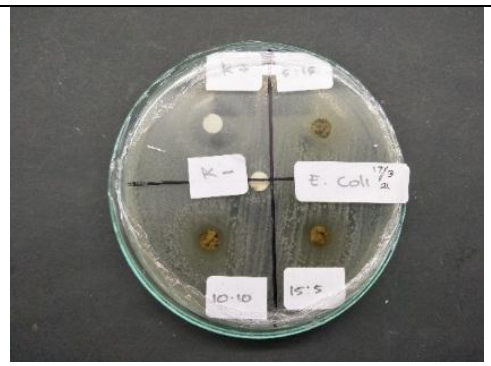

Replication 1 e.coli

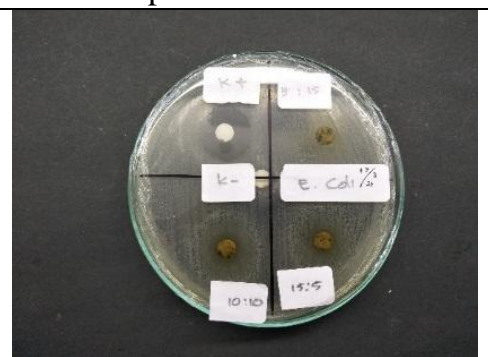

Replication 3 e.coli

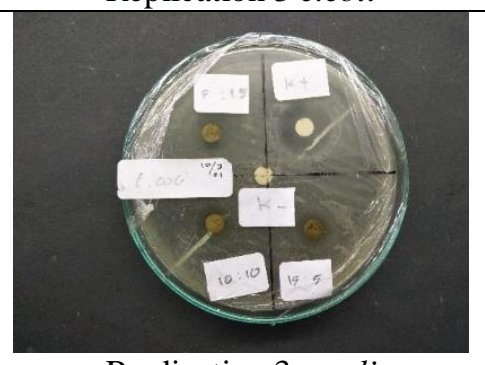

Replication 3 e.coli

Figure 1. Inhibition of the combination of ethanol extract of Miana and Kemuning leaves against Staphylococcus aureusand Escherichia coli

\section{A Natural Antiseptic Alternatif in Handsanitizer Gel (NAK3)}

The combination of $\mathrm{K} 3$ (15\%: $5 \%$ ) was then made a hand sanitizer gel. Hand sanitizer gel standard formulation coupled with a combination of Miana and Kemuning extracts (15\%: $5 \%$ ), the color changes to light brown (Figure 2).

\section{Antibacterial activity test of NAK3}

The antibacterial activity test of NAK3 was carried out using the disc diffusion method. How the disc diffusion works, namely hand sanitizer gel is absorbed on disc paper and attached to agar media that has been inoculated with Staphylococcus aureus and Escherichia coli bacteria then incubated for 24 hours and observed the inhibition zone in the area around the disc paper (Darsana et al., 2012).

The negative control was an empty hand sanitizer gel base without extract, which was used to see if the gelling agent used had antibacterial activity, which could later bias the study's results. 


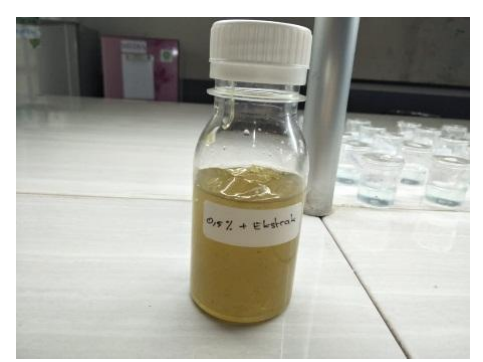

Figure 2. A Natural Antiseptic K3 (NAK3)

Meanwhile, the positive control used was the hand sanitizer gel formulation brand " $\mathrm{D}$ " which has a working mechanism by disrupting the bacterial cell membrane thereby reducing the ability of the cell membrane to produce ATP as an energy source for bacteria. In this study, a natural antiseptic with a combination of Miana and Kemuning extracts (15\%: 5\%) was made.

Hand sanitizer gel making uses a carbomer 940 base which functions as a gelling agent and has the advantage of being able to produce a clear gel. In this study, the carbomer 940 used in the manufacture of the hand sanitizer gel formulation was $0.5 \%$. Carbomer 940 which has been dispersed in water is then stirred rapidly to prevent agglomerates, then TEA is added to adjust the desired $\mathrm{pH}$, which is between 4.5-6.5 which corresponds to the $\mathrm{pH}$ of the skin. In the NAK3 made, it is necessary to add methylparaben which is intended as a preservative to prevent microorganisms in the hand sanitizer gel formulation. The addition of propylene glycol in the formulation has a function as an emollient so that when the hand sanitizer gel formulation is used, the hands do not feel dry. The addition of green tea to the formulation is intended to provide a pleasant aroma from the hand sanitizer gel formulation made.

The results of the antibacterial activity test showed that the NAK3 had an antibacterial activity which was characterized by an inhibition zone marked by the formation of a clear zone against Staphylococcus aureus and Escherichia coli which can be seen in Figure 3.

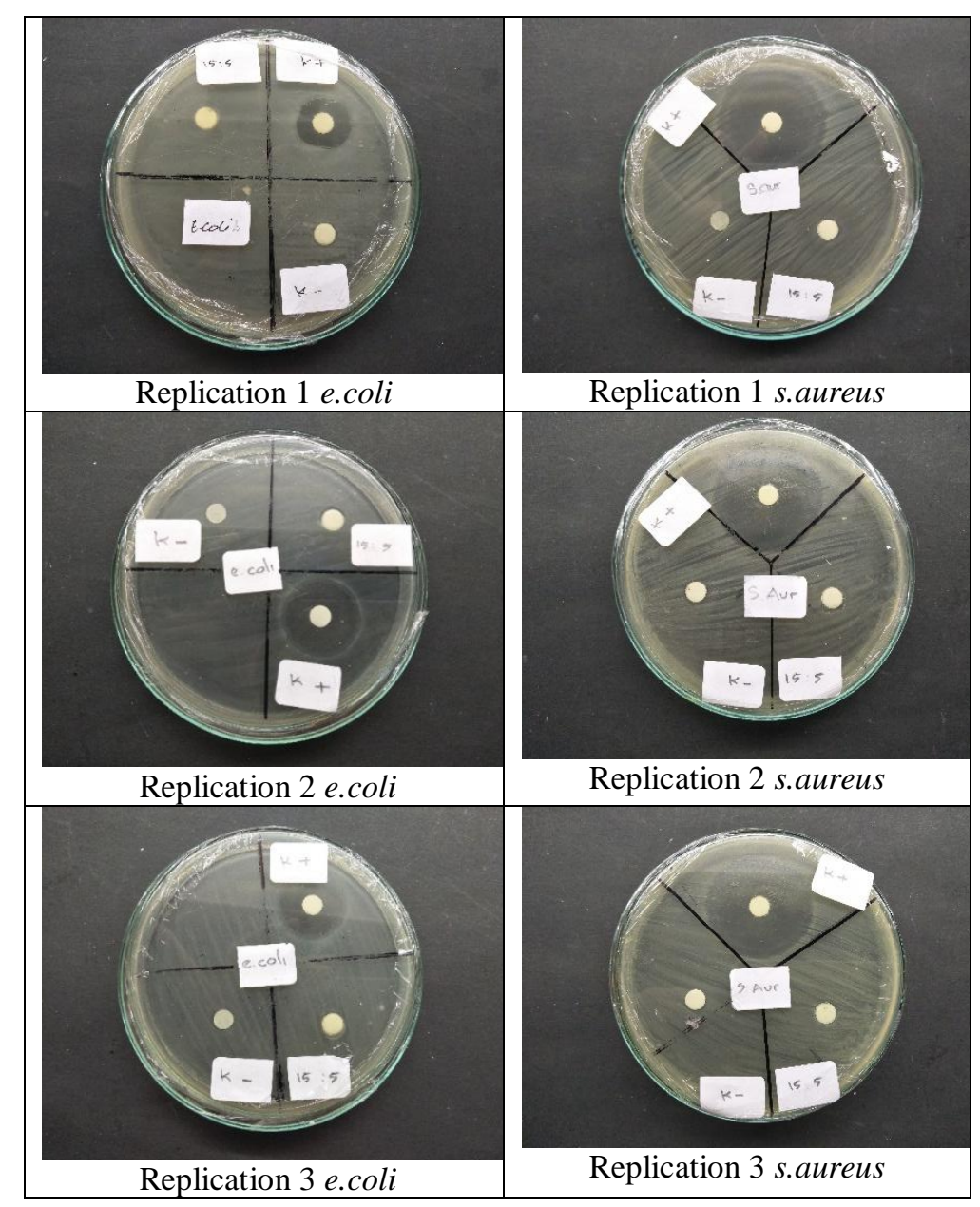

Figure 3. Inhibition of the NAK3 on Staphylococcus aureus and Escherichia coli 
Table 3. Diameter of the inhibition zone of the NAK3 on S.aureus and E.coli

\begin{tabular}{|c|c|c|c|c|c|}
\hline \multirow{2}{*}{ No. } & \multirow{2}{*}{ Treatment } & \multicolumn{3}{|c|}{ Inhibition Zone Diameter } & \multirow[b]{2}{*}{ Average } \\
\hline & & Replication I & Replication II & Replication III & \\
\hline \multicolumn{6}{|c|}{ Staphylococcus aureus } \\
\hline 1. & Control(+) & $27,00 \mathrm{~mm}$ & $28,00 \mathrm{~mm}$ & $27,00 \mathrm{~mm}$ & $27,33 \mathrm{~mm}$ \\
\hline 2. & K3 (15\%: $5 \%)$ & $07,00 \mathrm{~mm}$ & $08,00 \mathrm{~mm}$ & $07,00 \mathrm{~mm}$ & 7,33 mm \\
\hline 3. & Control (-) & $00,00 \mathrm{~mm}$ & $00,00 \mathrm{~mm}$ & $00,00 \mathrm{~mm}$ & $00,00 \mathrm{~mm}$ \\
\hline \multicolumn{6}{|c|}{ Eschericia coli } \\
\hline 1. & Control(+) & $17,00 \mathrm{~mm}$ & $20,00 \mathrm{~mm}$ & $21,00 \mathrm{~mm}$ & $19,33 \mathrm{~mm}$ \\
\hline 2. & K3 $(15 \%: 5 \%)$ & $09,50 \mathrm{~mm}$ & $09,50 \mathrm{~mm}$ & $08,00 \mathrm{~mm}$ & 09,00 mm \\
\hline 3. & Control (-) & $00,00 \mathrm{~mm}$ & $00,00 \mathrm{~mm}$ & $00,00 \mathrm{~mm}$ & $00,00 \mathrm{~mm}$ \\
\hline
\end{tabular}

According to Table 3, the result of the negative control inhibition zone is $0 \mathrm{~mm}$. This shows that the gel-based hand sanitizer used does not have an antibacterial activity which is indicated by the absence of a clear zone around the disc, so it does not affect the antibacterial test results of the hand sanitizer gel containing a combination of Miana and Kemuning extracts (15\%: $5 \%$ ).

The positive control used in this study was the hand sanitizer gel brand "D". The active ingredient contained in the gel hand sanitizer brand "D" is Chloroxylenol. Chloroxylenol is a broad-spectrum antibacterial agent that can inhibit the growth of gram-positive and gramnegative bacteria. Chloroxylenol has a working mechanism by disrupting the bacterial cell membrane thus reducing the ability of the cell membrane to produce ATP as a source of bacterial energy. Gel hand sanitizer brand "D" has an average inhibition zone of $27.33 \mathrm{~mm}$ (against Staphylococcus aureus) and $19.33 \mathrm{~mm}$ (against Escherichia coli) bacteria, which means that they are in the very strong inhibition zone category range. This is because the gel hand sanitizer brand "D" contains $63 \%$ alcohol which has an activity to kill bacteria.

The results of the inhibition zone diameter of the NAK3 were $7.33 \mathrm{~mm}$ (against Staphylococcus aureus) and $09.00 \mathrm{~mm}$ (against Escherichia coli) bacteria which were included in the moderate category. The NAK3 did not show better antiseptic potential when compared to single extracts of Miana and Kemuning leaves. As in the research of (Tarigan et al., 2020), at a concentration of $15 \%$, Miana actually showed a strong category of inhibition $(12.80 \mathrm{~mm})$ against S.aureus, as well as research by (Tahir et al.,
2018), at a concentration of 5\% Kemuning, it actually showed a strong category of inhibition $(12 \mathrm{~mm})$ against $S$. aureus and $E$. $\operatorname{coli}(9.3 \mathrm{~mm})$ in the moderate category. Based on the comparison of the NAK3 extract, it can be seen that the extract that is more potent as an antibacterial is the extract of Miana Leaves, This is possible because the mechanism of action of antiseptic compounds in Miana leaves (Alkaloids and Tannis) is more optimal (Tarigan et al., 2020) than in Kemuning leaves, although qualitatively the content of antiseptic compounds in Kemuning is more varied (Irwin et.al., 2015). Alkaloids have the underlying structure for the development of several antibacterials with diverse actions. The mechanism of alkaloids as antibacterials is to disrupt the building blocks of bacteria in peptidoglycan cells, thereby preventing the formation of intact cell walls and causing bacterial death (Leen Othman, et.al., 2019). The mechanism possessed by the tannin antibacterial effect is antibacterial by applying inhibitory protein synthesis. Antibacterial effect of tannins through reactions to cell membranes, inactivation of enzymes, and inactivation of genetic material. tannin antimicrobial activity include inhibition of extracellular microbial enzymes, deprivation of the substrates required for microbial growth or direct action on microbial metabolism through inhibition of oxidative phosphorylation (Kurhekar, J.V., 2016).

\section{Physical Evaluation of the NAK3}

The purpose of formulation evaluation is to determine the quality of a formulation and to ensure that the formulation has characteristics that correspond to 
predetermined characteristics (standard formulation). Formulation evaluation includes organoleptic test, homogeneity test, $\mathrm{pH}$ test, spreadability test, adhesion test, protective power test, and drying time speed test. A physical stability test was performed on day 0 , day 7 , day 14 , day 21 , and day 28 (Table 4 ).

Table 4. The results of the evaluation of the NAK3

\begin{tabular}{rll}
\hline Evaluation gel & Result & Standart \\
\hline Organoleptic & Semi solid & Semi solid \\
a. Texture & a. Semi solid & a. Semi solid \\
b. Colour & b. light brown & b. Transparent \\
c. Smell & c. odorless & c. - \\
Homogeneity & homogeneous & homogeneous \\
pH & 5,8 & $4,5-6,5$ (Naibaho et al., 2013) \\
Spreadability & 6,59 & $5-7 \mathrm{~cm}$ (Wasiaturrahmah, 2018) \\
Adhesion & 7,41 & $\geq 4$ detik(Yati et al., 2018) \\
\hline
\end{tabular}

The NAK3 evaluation results (Table 4) are based on the organoleptic formulation of the gel that is formed according to the standard, as well as the value of homogeneity, $\mathrm{pH}$ (according to skin $\mathrm{pH}$ ), dispersibility, and stable adhesion after 28 days of storage.
The drying speed test shows the time required for NAK3 to dry on the skin of the palms (front and back of the skin of the palms with an area of $40-50 \mathrm{~cm} 2$ ). The drying time test results can be seen in Figure 4.

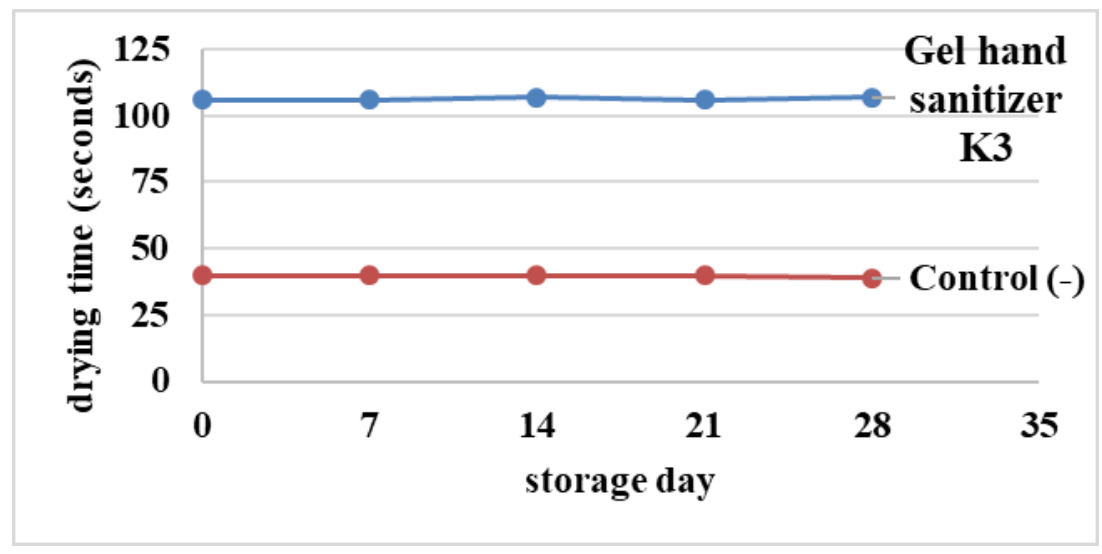

Figure 4. Graph depicting the drying time of NAK3 after 28 days in storage

Based on Figure 4, the NAK3 requires a longer time than the control comparison gel (), because the NAK3 does not contain alcohol while the comparison uses $63 \%$ alcohol which can speed up the drying process.

\section{CONCLUSION}

The hand sanitizer gel formulation from a combination of ethanol extract of Miana and Kemuning leaves ratio (15\%: 5\%) (NAK3) has the potential to be a natural antiseptic with marked $7.33 \mathrm{~mm}$ inhibition (against Staphylococcus aureus) and $09.00 \mathrm{~mm}$ (against Escherichia coli) which were included in the moderate category. The NAK3 has good physical stability during the storage period.

\section{ACKNOWLEDGEMENT}

Thank you to the Directorate of Research and Community Service (DRPM) for funding this research with contract number 9/E1/KPT/2021 from the Budget Implementation List (DIPA) Deputy for Research and Development Strengthening Ministry of Research and Technology/National Research and Innovation Agency in 2021. 


\section{REFERENCES}

Asngad, A., R. Bagas, A., \& Nopitasari. (2018). Kualitas Gel Pembersih Tangan (Handsanitizer) dari Ekstrak Batang Pisang dengan Penambahan Alkohol, Triklosan dan Gliserin yang Berbeda Dosisnya. $\quad 4(2), \quad 61-70$. https://doi.org/10.23917/bioeksperimen.v4i 1.2795

Ati, A. A. N. (2019). Formulasi dan Uji Stabilitas Gel Hand Sanitizer Ekstrak Etanol Daun Alpukat (Persea americana Mill.). Skripsi, Fakultas MIPA Universitas Al-Ghifari.

Darsana, I., Besung, I., \& Mahatmi, H. (2012). Potensi Daun Binahong (Anredera cordifolia). Indonesia Medicus Veterinus, 337-351.

L. Angga, I., Prenggono, M. D., \& Budiarti, L. Y. (2015). Identifikasi Jenis Bakteri Kontaminan Pada Tangan Perawat di Bangsal Penyakit Dalam RSUD ULIN Banjasrmasin Periode Juni-Agustus 2014. Berkala Kedokteran, 11(1), 11-18.

Leen Othman, Ahmad Sleiman, and Roula M.Abdel-Massih. Antimicrobial Activity of Polyphenols and Alkaloids in Middle Eastern Plants. Front. Microbiol, 10: 128.

https://doi.org/10.3389/fmicb.2019.00911

Mawan, A. R., Indriwati, S. E., \& Suhadi. (2017). Aktivitas Antibakteri Ekstrak Metanol Kulit Batang Tumbuhan Salam (Syzygium polyanthum) Terhadap Pertumbuhan Bakteri Escherchia coli. Jurnal Bioedukasi Universitas Jember, 15(1), 8-13.

Mpila, D. ., Fatimawali, \& Wiyono, W. I. (2012). Uji Aktivitas Antibakteri Daun Mayana (Coleus atropurpureus [L] Benth) Terhadap Staphylococcus aureus, Escherichia coli dan Pseudomonas aeruginosa secara invitro. Uji Aktivitas Antibakteri Daun Mayana (Coleus Atropurpureus [L] Benth) Terhadap Staphylococcus Aureus, Escherichia Coli Dan Pseudomonas Aeruginosa Secara in-Vitro, 13.

Naibaho, D. H., Yamkan, V. Y., \& Weni, W. (2013). Pengaruh Basis Salep Terhadap Formulasi Sediaan Salep Ekstrak Daun Kemangi (Ocinum sanchum L.) pada Kulit
Punggung Kelinci yang dibuat Infeksi Staphylococcus aureus. Jurnal Ilmiah Farmasi, 27-33.

Ningsih, W., Firmansyah, \& Anggraini, S. (2016). Formulasi dan Uji Aktivitas Antibakteri Gel Pembersih Tangan Ekstrak Etanol Daun Kembang Bulan (Tithonia diversifolia (Hemsley) A. Gray). Jurnal Ilmiah Farmasi, 79-85.

Jaya Vikas Kurhekar. (2016). Tannins Antimicrobial Chemical Components. International Journal of Technology and Science, 9(3), 5-9.

Rizal, M., Yusransyah, \& Sofi, N. S. (2016). Uji Aktivitas Antidiare Ekstrak Etanol 70\% Kulit Buah Jengkol (Archidendron pauciflorum (Benth.) I.C.Nielsen) terhadap Mencit Jantan Yang Diinduksi Oleum Ricini. Jurnal Ilmiah Manuntung, 2(2), 131-136.

Shu, M. (2013). Formulasi Sediaan Gel Hand Sanitizer Dengan Bahan Aktif Triklosan 0,5\% Dan 1\%. Jurnal Ilmiah Mahasiswa Universitas Surabaya, 2(1), 1-14.

Sinaga, L. R. V., Seri, A. M., \& Henny, A. B. (2020). Sosialisasi Perilaku Cuci Tangan pakai Sabun di Desa Sawo Sebagai Bentuk Kepedulian Terhadap masyarakat Ditengah Mewabahnya Virus Covid-19. Jurnal Abdimas Mutiara, 1(September), 19-28.

Tahir, D. N. ., Mustapa, M. ., \& Abdulkadir, W. (2018). Uji Aktivitas Antibakteri Esktrak Kemuning (Murayya paniculata) terhadap Bakteri Eschericia Coli dan Staphylococcus aureus. Skripsi, Universitas Negeri Gorontalo Repository.

Tarigan, I. L., Sari, A. K., Huda, C., Jovanncha, C., \& Muadifah, A. (2020). Phytochemical Screening and Quantitative Analysis of Coleus arthropurpureus Ethyl Acetate Fraction and Antibacterial Activity Against Staphylococcus aureus. ALKIMIA : Jurnal Ilmu Kimia Dan Terapan, 4(1), 17-23. https://doi.org/10.19109/alkimia.v4i1.5123

Wasiaturrahmah, Y., \& Jannah, R. (2018). Formulation And Physical Properties Test Of Hand Sanitizer Gel From Bay Leaf Extract (Syzygium polyanthum). Borneo Journal of Pharmascientech, 2(2), 87-94. 
Widyawati, L., Mustariani, Aprilia, B. A., \& Purmafitriah, E. (2017). Formulasi Sediaan Gel Hand Sanitizer Ekstrak Etanol Daun Sirsak (Annona muricata Linn) sebagai Antibakteri terhadap Staphylococcus aureus. Jurnal Farmasetis, 6(2), 47-57.

Irwin R. A. Menezes, Temi'stocles I. Santana, Victor J. C. Varela, Rogerio A. Saraiva, Edinardo F. F. Matias, Aline A. Boligon, Margareth L. Athayde, Henrique D. M. Coutinho, Jose G. M. Costa, and Joa o B. T. Rocha (2015). Chemical composition and evaluation of acute toxicological, antimicrobial and modulatory resistance of the extract ofMurraya paniculata. Pharmaceutical Biology, 53(2): 185-191. https://doi.org/10.3109/13880209.2014.913 068.
Yati, K., Mahdi, J., Misri, G., Mardiastuti, \& Lusi, P. D. (2018). Pengaruh Variasi Konsentrasi Hidroxy Propyl Methyl Cellulose (HPMC) terhadap Stabilitas Fisik Gel Ekstrak Tembakau (Nicotiana tabaccum L.) dan Aktivitasnya terhadap Streptococcus mutans. . Pharmaceutical Sciences and Research (PSR), 5(3), 133141.

Yusriana, C. S., Chrisnawan, S. B., \& Trisna, D. (2014). Uji Daya Hambat Infusa Daun Nangka (Artocarpuus heterophyllus) terhadap Pertumbuhan Bakteri Staplylococcus aureus. Jurnal Permata Indonesia, 5(2), 1-7. 